\section{THE SPIRITUAL QUALITY IN FACILITATING A TRANSFORMATION TOWARDS INTEGRAL SUSTAINABILITY: THE CASE OF REAL ESTATE DEVELOPMENT}

\author{
Tanapon Panthasen ${ }^{1}$ \\ John Motloch ${ }^{2}$ \\ Vimolsiddhi Horayangkura ${ }^{3}$
}

\begin{abstract}

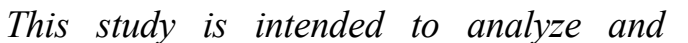

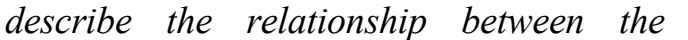

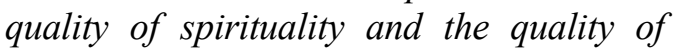

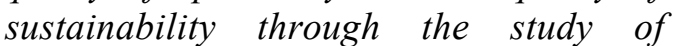

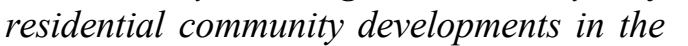

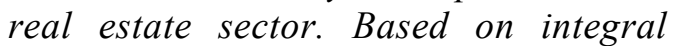

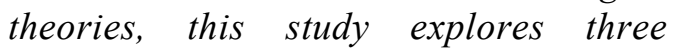

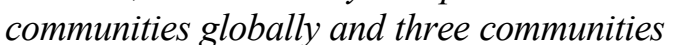

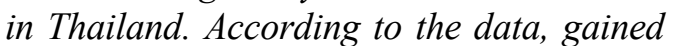

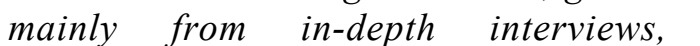

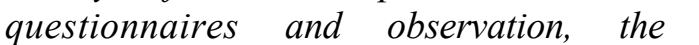

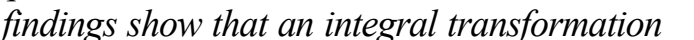

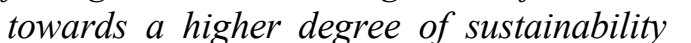

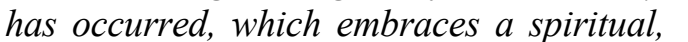

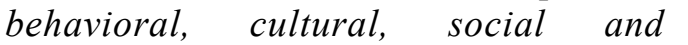

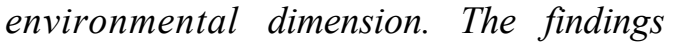

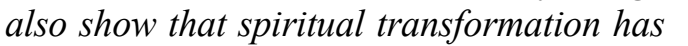

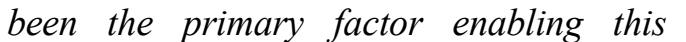

\footnotetext{
${ }^{1}$ Lecturer, Division of Urban and Environmental Planning, Faculty of Architecture, Kasetsart University, Bangkok, Thailand

${ }^{2}$ Professor, Department of Landscape Architecture, College of Architecture and Planning, Ball State University, Muncie, USA

${ }^{3}$ Professor, Faculty of Architecture and

Planning, Thammasat University,

Pathumthani, Thailand
}

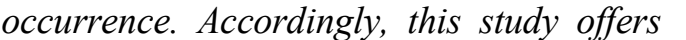

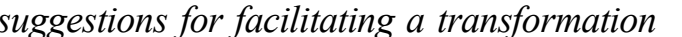

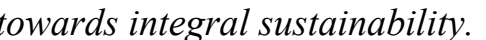

\section{Introduction}

Since World War II, $\quad \square\|\| \| \square \square \square$ has internationally referred to attempts to help poor nations become richer through the paradigm of capitalism, the mainstream western economic view that emphasizes simply material growth and wealth rather than other human development dimensions and resource limits (Puntasen 2000a: 499501, Wasee 2002: 4-5). The resultant environmental and social degradation worldwide has proved that this narrow definition and approach are inappropriate if the goal is to enhance sustainability and the quality of life. Therefore, the World Commission on Environment and Development (WCED 1989) has publicized

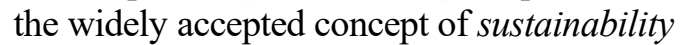
as a new paradigm of development to resolve the problems of poverty, inequality and environmental degradation. Although the WCED has left specific goals to be defined regionally, there is general agreement that sustainability must pursue the triple bottom line of environmental responsibility, social justice and economic vitality. Unfortunately, numerous thinkers, such as Beck (2001), Segschneider (2002) and Motloch et al. (2005), have revealed that short-term economics is still often overemphasized and social justice is often underemphasized.

Even worse, according to the extensive review of the literature and the keyinformant interviews in the pilot study, there have been very few integrated discussions about and studies of sustainable 
development in the real estate industry ${ }^{4}$ although it consumes considerable quantities of natural resources and constitutes a large part of every country's national budget. Furthermore, those discussions and studies of sustainable development are fragmented because, though most of them focus on the various dimensions of life, they exclude the important sense of environmental consciousness and awareness, which are $\square \square \| \square$ dimensions that have long been publicized as crucial factors of sustainable well-being, as seen in Schumacher (1973), Buddhadasa (1990), and Santitham (2006) for example.

For the reasons explained above, the $\square 11$

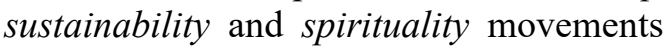
have increasingly challenged this common weakness and advocated $\square \square \square \square \square \square$

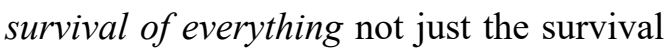
of humankind (Puntasen 2000a: 690).

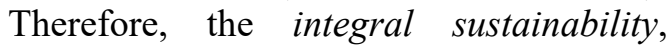
explored herein, pursues the goal of sustaining the common survival of everything. It is believed that once integral sustainability has become commonly understood, people and cultures will internalize the integral paradigm; and spiritual development will cease to be a limiting factor in achieving a transformation towards sustainability. These claims are based on converging integral theories and sustainable real estate development concepts in a research that has been undertaken to explore the degree of sustainability and the influential forces that have facilitated a transformation towards integral sustainability in the real estate industry. It is expected that it will be found that:

\footnotetext{
${ }^{4}$ The real estate industry includes aspects of economics, planning, community and housing development, various areas of architecture, as well as construction and property management.
}

Firstly, an integral transformation toward integral sustainability, which embraces spiritual, behavioral, cultural, social and environmental dimensions, has occurred.

Secondly, that spiritual development is the primary factor enabling this occurrence.

Third, integral sustainability, or a higher degree of sustainability, depends on a higher degree of spiritual quality.

This paper is divided into five sections: namely (1) convergence of integral theories; (2) convergence of integral theories and sustainable real estate development; (3) research design; (4) findings about relationships among influential forces that have facilitated a transformation toward integral sustainability; and (5) conclusions and recommendations.

\section{Integral theories}

This study originated as a result of the attempt to contend that integral sustainability in the real estate industry actually needs a spiritual core, by using two main concepts in $\square \square \square \square ा \| \square \square \square \square$.

The first one is the emphasis on the interdependent relationship between humans, especially the spiritual dimension and the physical environment, based on the law of nature. Buddhadasa (1990) explains this law of nature, which is the heart of BuddhaDhamma, as follows:

... Nothing happens except through various causes and conditions ... Further, the causes and conditions of one thing are caused and conditioned by others. These interactions of conditionality extend through the universe, mental and physical, 
connecting everything in a vast web of interdependence ... interconnectedness ... So supreme is this natural fact that

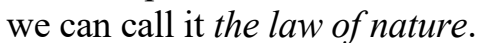

The second one is the emphasis on the importance of spiritual development. As Puntasen (2000b: 164) explains, humans with a highly developed mind or a high spiritual-quality possess a high degree of loving kindness that will lead to harmonic living among humans and all sentient beings, as well as all nature. Additional explanation can be found in the teaching of Buddhadasa (1990):

... If we understand all aspects of nature and conserve the law of nature within ourselves ... the external, physical aspect of nature will be able to conserve itself automatically.

However, to a certain extent, $\square \square \square \square \square$ has limitations regarding research methodology and the ability to analyze and briefly explain the international context of the real estate industry at present. Therefore,

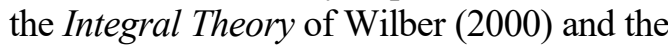

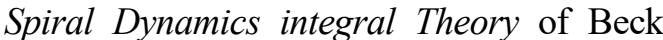
(URL) have been added to strengthen this study.

In explaining the natural law of interdependent relationships, Wilber (URL-a.) uses the word एा山ाण and explains it as follows:

Integral means comprehensive, inclusive, balanced, embracing. When it comes to human beings, integral means maps, models and practices that include the full spectrum of human potential, often summarized as exercising body, mind and spirit in self, culture and nature."
Such explanations imply a much higher level of interconnectivity and interdependence than the more familiar meaning of mixing and integrating.

Wilber (2000: 55-56 and 70-71) further explains that in any activity, one must consider four $\square \square \square\|\| \square$, as the four dimensions of life:

Mind, self or consciousness is the

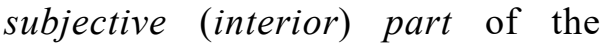
individual.

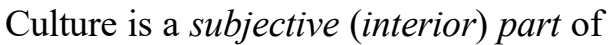
the human collective.

Health and behavior are the $\square \mid\|ा\| ा \|$ ( $\square \square\|\|$ L) $\square \square$ of the individual.

Lastly, social systems and environment are the $\square \square\|\|\|\| \square(\square\|\square\| \square) \square \square \square \square$ of the human collective.

All these dimensions are interrelated. So, one cannot ignore or separate any of these

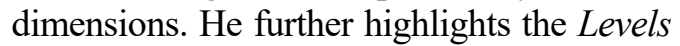
of development, based on abundant evidence showing that everything has evolved naturally and integrally, to higher levels and healthier forms that always include the qualities of their predecessors. For example

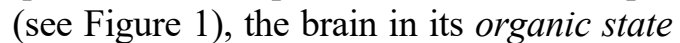

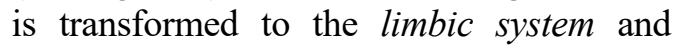
eventually to the human $\square \Pi\|\mid \omega\|{ }^{5}$ Cultural

\footnotetext{
${ }^{5}$ Although all vertebrate brains have the same basic three-part structure, the development of their constituent parts varies across the scale of evolution. Firstly, arising as a natural outgrowth in reptiles, the organic state, reptilian complex, is the original and the least complex brain. It has integrative functions to support the continuation of life such as blood system, pain sensitivity and alertness. Secondly, limbic system emerged in birds, the more highly evolved animal. This limbic system has become the base of fundamental emotions such as love and fear.
} 
and social systems are transformed from basic to complicated ones, from

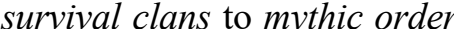

$\square \square \| \square$ to $\square\|\|\|\|$ cultures and societies.

The contention herein is that these transformations are $\square$ facilitated by the spiritual development from $\square[\| \square$ to the

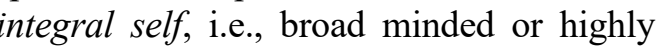
developed persons in all dimensions.

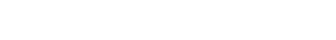

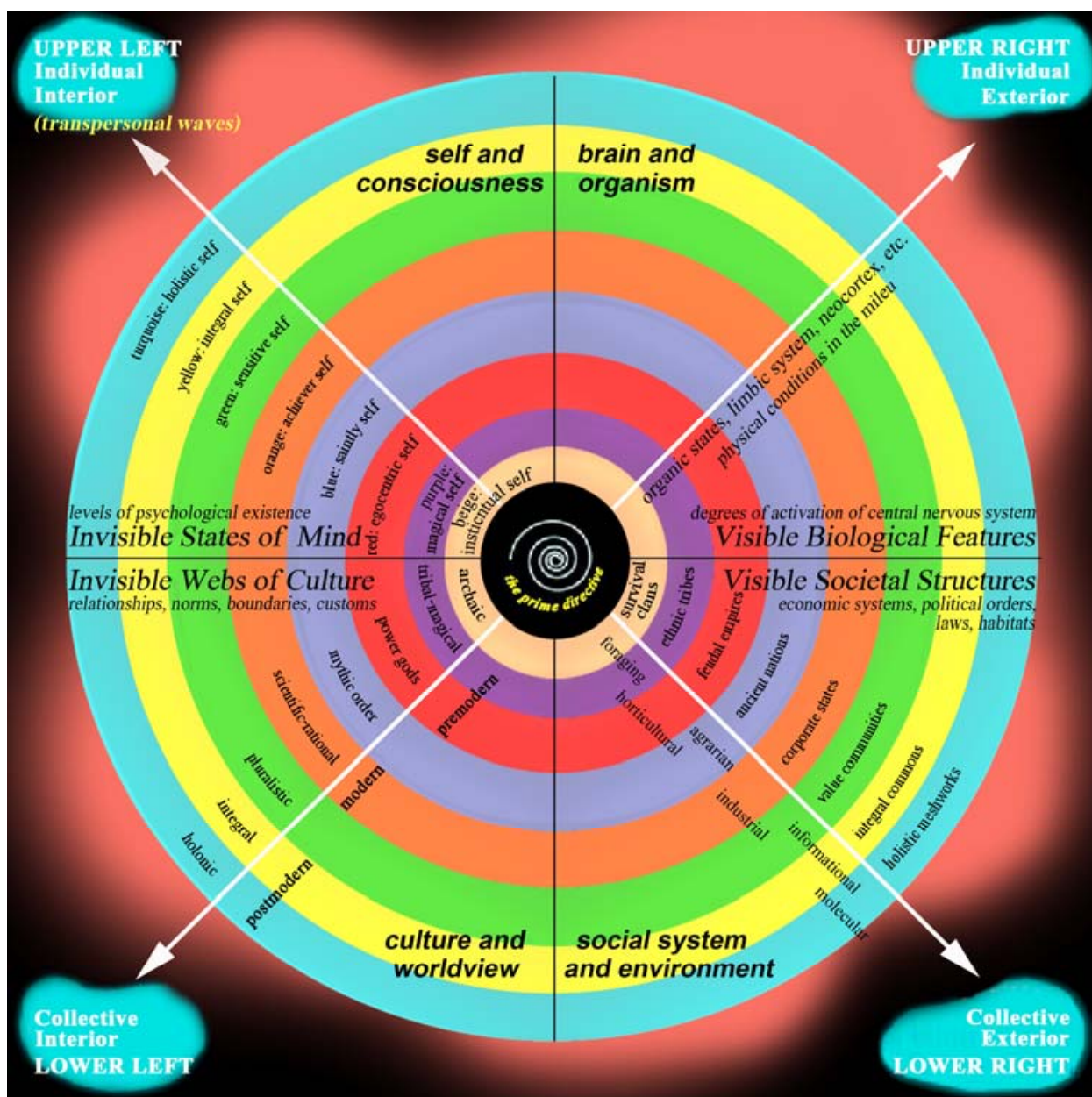

Thirdly, neocortex emerged in mammals and progressively evolved to the most complex stage of brain in human beings, in whom cognitive ability is the highest. (Toga 2002 and Tangjai 1995: 89-91) 
While Wilber developed his integral concepts, Beck and Cowan (2001) developed a $\square \square \| \square \square \square \square \square \square$ theory. Wilber (2000: 6-7) explains briefly that this theory focuses on a transformation to progressively higher levels of bio-psychosocial awareness. Accordingly, it takes a systems approach to human development, seeing individuals and cultures proceeding through progressively more complex perceptions of the challenges of existence, coping strategies to address these challenges and the social manifestations and environment they create to address these problems.

In this theory, Beck and Cowan (2001: 3) introduce the concept of $\square \square\|\square\| \square \square$, the spiritual life-qualities that "carry the coded instructions of our thinking systems" and represent these in terms of different colors of spiral dynamics. Furthermore, Beck and Cowan (2001: 115-142) have developed research methods and tools to study the dynamics of memes in people, companies, communities and countries, as well as the

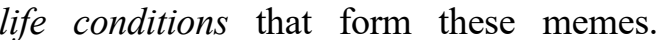
According to Wilber (2000: 7), the outcome of this study helps to identify integral solutions affecting large-scale systems change in and among various sectors and societies internationally. Beck and Wilber became partners in 1999. Beck then created

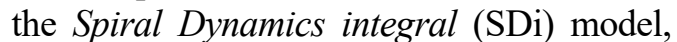
Figure 1 and as Wilber (URL-b.) confirms, this model is a simple but elegant map of human growth and development that allows intuitive ease of understanding.

\begin{tabular}{|c|c|c|c|c|c|c|}
\hline Period & Meme code & Spirituality & Behavior & Culture & $\begin{array}{l}\text { Societal } \\
\text { Structure }\end{array}$ & Built Environment \\
\hline 30 yrs ago & Turquois & Holistic & $\begin{array}{c}\text { Planetary } \\
\text { concerning }\end{array}$ & Earth changes & $\begin{array}{c}\text { Holistic } \\
\text { meshworks }\end{array}$ & $\begin{array}{c}\text { Sustainable- } \\
\text { Synergy of all living }\end{array}$ \\
\hline 50 yrs ago & Yellow & Integral & $\begin{array}{c}\text { Integrative } \\
\text { learning }\end{array}$ & Natural systems & $\begin{array}{l}\text { Informational/ } \\
\text { integral commons }\end{array}$ & $\begin{array}{c}\text { Sustainable- self } \\
\text { sufficient }\end{array}$ \\
\hline 150 yrs ago & है & Sensitive & Caring & Pluralistic & $\begin{array}{c}\text { Value } \\
\text { communities }\end{array}$ & $\begin{array}{c}\text { Sustainable - green } \\
\text { issue }\end{array}$ \\
\hline 300 yrs ago & $\underline{\partial}$ & Achiever & $\begin{array}{c}\text { Success } \\
\text { driven }\end{array}$ & $\begin{array}{c}\text { Scientific rational/ } \\
\text { materialism }\end{array}$ & Corporate states & Modern/ Postmodern \\
\hline 5,000 yrs ago & : & Saintly & Faithful & Mythic order & Ancient nations & Classic \\
\hline 10,000 yrs ago & $\mid \begin{array}{l}\overrightarrow{0} \\
\vec{z}\end{array}$ & Egocentric & Conquest & Power gods & Feudal empires & Primitive \\
\hline 50,000 yrs ago & 总 & Animistic & Folk & Tribal magical & Ethnic tribes & Early-primitive \\
\hline $\begin{array}{c}100,000 \text { yrs } \\
\text { ago }\end{array}$ & Beige & Instinctive & $\begin{array}{l}\text { Staying } \\
\text { alive }\end{array}$ & Archaic & Survival clans & None \\
\hline
\end{tabular}

Figure 2 Integral Evolution.

Source: Beck (2001), Beck (2004) and Wilber (2000: 43) combined and the characters of built environment have been added by the authors. 


\section{Integral evolution towards sustainable real estate development}

To check if the SDi model has the potential to explain the interdependent relationship between spirituality and sustainability, an analysis was conducted in the pilot study based on the convergence of the SDi theory and the history of sustainable architecture and human-built habitat (in the other words,

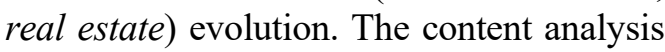
reveals that an integral evolution has occurred.

As shown by Figure 2, in archaic culture, people as instinctive selves (BEIGE) lived similarly to other animals in survival clans. In the magical culture, humankind's animistic self (PURPLE) started to imagine and create boundaries and tents differently according to ethic tribes. In the power-gods culture, the egocentric self (RED) began to separate from nature, to establish communities and to invade each other to acquire more material property for strengthening feudal empires. In the mythic-order culture, the saintly self (BLUE) constructed over-sized buildings to show respect for the "higher power" and for the ancient nations. In the scientific-rational culture, the achiever self (ORANGE) designed modern architecture that reflects high-technology, economic power and success, according to the concepts of corporate states and

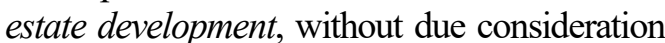
to local culture and nature. More recently, excessive consumption has forced human consciousness to evolve towards a more sensitive self (GREEN), so that environmentally friendly, pluralistic and highly valued communities can be created. However, the built environment will not become truly environmentally friendly until humans embrace integral qualities (YELLOW) at the next level. In pursuit of this level, this paper investigates sustainable communities to see how sustainable real estate development transformation has been facilitated.

\section{Research design}

The integral research framework of this

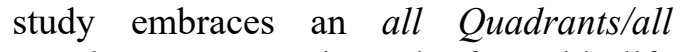
$\square \square \square$ concept. It views the favorable life conditions at individual and collective levels that have facilitated the transformation of communities and key players (developers, architects and homeowners) towards healthier levels. Qualitative and quantitative approaches were integrated and used according to the suitability to each part of the research as shown in part 1,2 and 3 of Figure 3.

The major research tools are the guides for in-depth interview and questionnaire application. The guidelines and indicators used are based on various integral and real estate concepts.

\section{Interview guide}

A semi-structured set of questions, along with a method of content analysis, were used to detect memes and to identify the degree to which interviewees and community members shifted spiritually away from materialism and egoism. A higher degree means a higher spiritual quality. In addition, this set of questions was used to reveal life conditions that affect self-transformation. (See a description of the question design in Beck and Cowan 2001: 117.) 


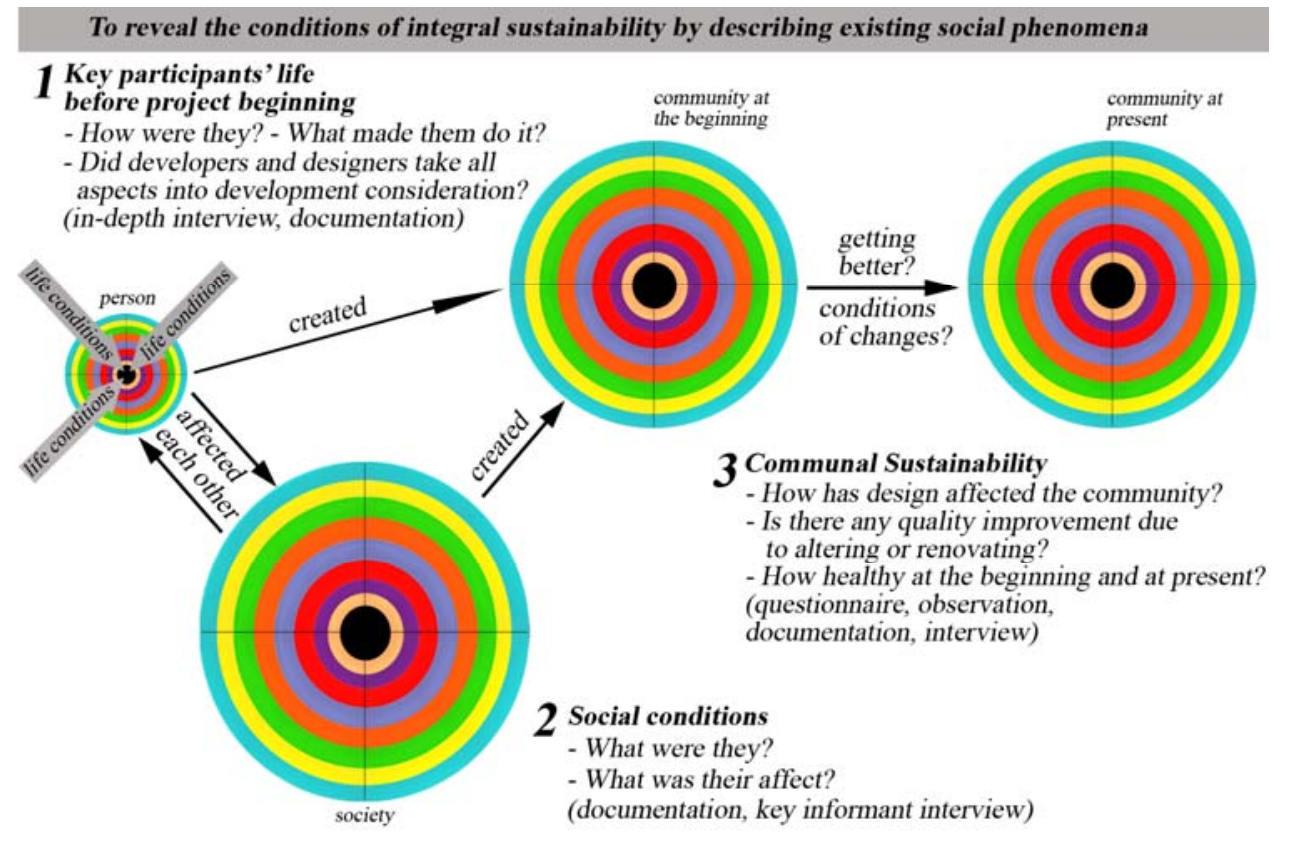

Figure 3:

\section{Set of questionnaires}

Although the set of questionnaires consisted of many parts, the main part was the attitude test that let homeowners evaluate the intensity of 5 memes owned by themselves and by their community. A sliding scale of 1 to 5 is used for each meme belonging to each sub-category in each Quadrant, as shown in Figure 4. Once all questionnaires were completed, the input was calculated and analyzed by statistical method to identify the dominating memes or sustainable qualities in each Quadrant and for the overall situation. 
SPIRITUALITY Dominating VMEME =?

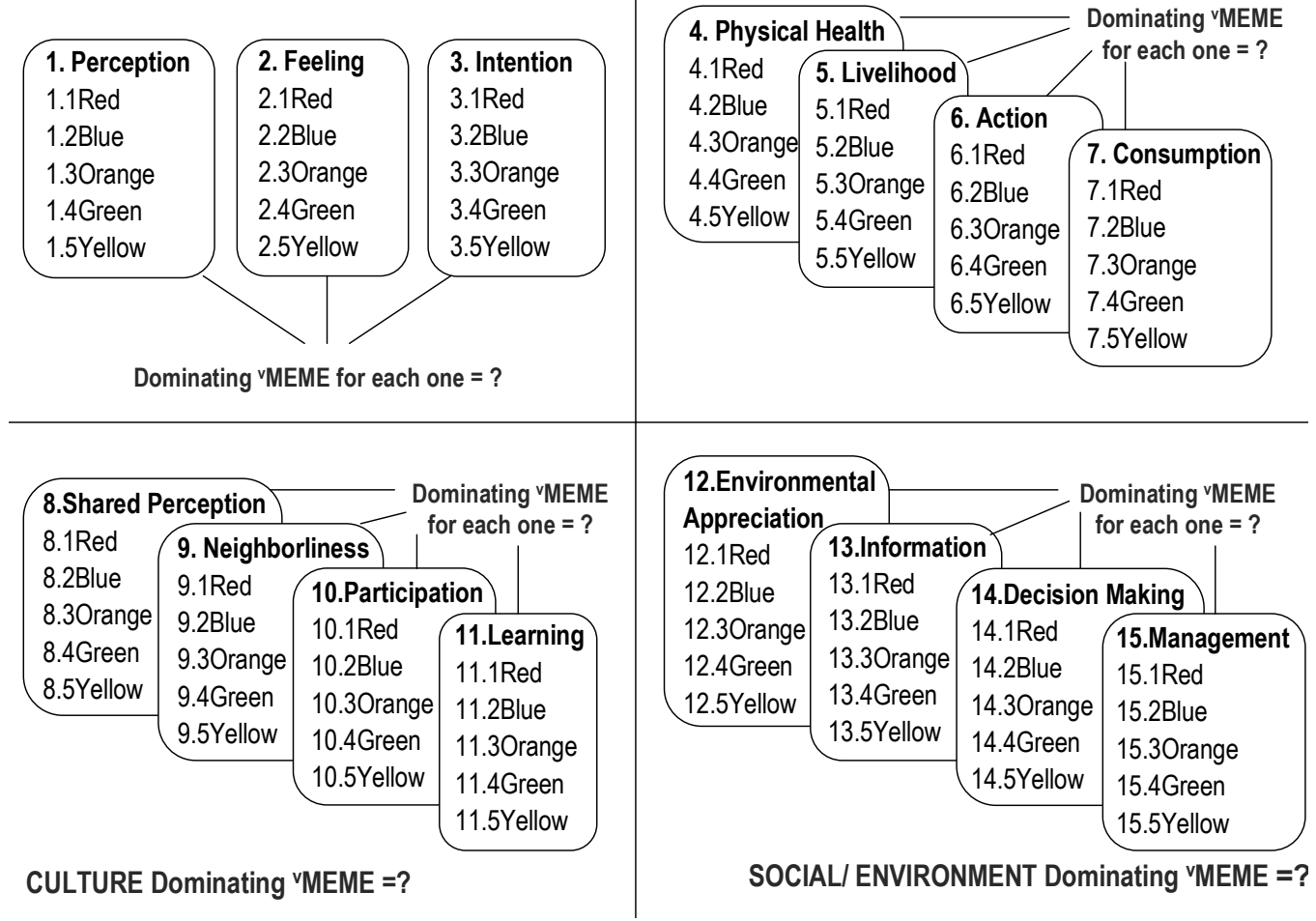

Figure 4 Use of Quadrants to compose the indicators of measurement for questionnaires.

Note: The color codes, namely Red, Blue, Orange, Green, and Yellow, shown in this figure were not shown in questionnaires because they were represented by various statements similar to those shown in Figure 5, making the questionnaire complete.

\section{Measurement}

Figure 5 gives an example of indicators and measurements, using six meme color codes (from RED to TURQUOISE) and corresponding meme characters, in identifying spiritual quality and other sustainable qualities in the remaining three Quadrants; namely behavioral, cultural, as well as social and environmental qualities. 


\begin{tabular}{|c|c|c|c|c|c|}
\hline \multirow{3}{*}{$\begin{array}{l}\text { Levels of } \\
\text { Quality }\end{array}$} & \multicolumn{5}{|c|}{ Characters of Corresponding Answers to the Survey Questions } \\
\hline & \multirow{2}{*}{$\begin{array}{l}\text { Spirituality: } \\
\text { Perception of the } \\
\text { world }\end{array}$} & \multirow{2}{*}{$\begin{array}{l}\text { Behavior: } \\
\text { Livelihood }\end{array}$} & \multirow{2}{*}{$\begin{array}{c}\text { Culture: } \\
\begin{array}{c}\text { Environmental } \\
\text { participation }\end{array} \\
\end{array}$} & \multicolumn{2}{|c|}{ Social system and Environment: } \\
\hline & & & & $\begin{array}{l}\text { Operating systems } \\
\text { of community }\end{array}$ & Neighborhood \\
\hline Turquoise & $\begin{array}{l}\text { a single, dynamic } \\
\text { organism with its own }\end{array}$ & $\begin{array}{l}\text { unification across } \\
\text { races and nations for } \\
\text { global solutions }\end{array}$ & $\begin{array}{l}\text { cooperating with } \\
\text { global networks to } \\
\text { address issues } \\
\text { impacting all life } \\
\text { forms }\end{array}$ & $\begin{array}{l}\text { holistic blend of insights } \\
\text { from anywhere, for } \\
\text { purposes impacting the } \\
\text { Global Village }\end{array}$ & $\begin{array}{l}\text { Global Village } \\
\text { where diversity is } \\
\text { seen as a norm }\end{array}$ \\
\hline Yellow & $\begin{array}{l}\text { a diversity of life and } \\
\text { natural systems, facing } \\
\text { a destructive situation }\end{array}$ & $\begin{array}{l}\text { based on integrated } \\
\text { sciences and views to } \\
\text { create long term well- } \\
\text { being }\end{array}$ & $\begin{array}{l}\text { teaching children } \\
\text { about living on Earth } \\
\text { in the broad pictures }\end{array}$ & $\begin{array}{l}\text { networks that yields } \\
\text { competency to achieve } \\
\text { the problems as } \\
\text { needed }\end{array}$ & $\begin{array}{c}\text { a place for learning } \\
\text { to live respectfully } \\
\text { with Nature }\end{array}$ \\
\hline Green & $\begin{array}{c}\text { where people join } \\
\text { hands and hearts to } \\
\text { prosper in peace and } \\
\text { equality }\end{array}$ & $\begin{array}{l}\text { promoting equal right } \\
\text { and opportunity or } \\
\text { environmental } \\
\text { conservation }\end{array}$ & $\begin{array}{l}\text { living in an } \\
\text { environmentally } \\
\text { responsible manner }\end{array}$ & $\begin{array}{l}\text { pulling everyone } \\
\text { together to make } \\
\text { mutual decisions that } \\
\text { care for sensitivity }\end{array}$ & $\begin{array}{l}\text { deteriorated, but } \\
\text { people joined hands } \\
\text { to restore its } \\
\text { healthiness }\end{array}$ \\
\hline Orange & $\begin{array}{l}\text { the market place of } \\
\text { unlimited } \\
\text { opportunities and } \\
\text { possibilities for } \\
\text { success }\end{array}$ & $\begin{array}{l}\text { technology-oriented } \\
\text { to benefit from } \\
\text { economic growth }\end{array}$ & $\begin{array}{l}\text { joining some } \\
\text { sustainable activities, } \\
\text { not disturbing the } \\
\text { quality of 'good life' }\end{array}$ & $\begin{array}{l}\text { entrepreneurism with } \\
\text { plans to reach goals to } \\
\text { better the self and } \\
\text { some others }\end{array}$ & $\begin{array}{l}\text { polluted and } \\
\text { crowded with } \\
\text { buildings }\end{array}$ \\
\hline Blue & $\begin{array}{l}\text { under control of } \\
\text { destiny, principles, } \\
\text { and 'higher power' }\end{array}$ & $\begin{array}{l}\text { related to tradition or } \\
\text { things that have been } \\
\text { studied and well } \\
\text { planned }\end{array}$ & $\begin{array}{l}\text { keeping just private } \\
\text { home neat as feeling } \\
\text { uninterested in } \\
\text { environmental changes }\end{array}$ & $\begin{array}{l}\text { maintaining a clear } \\
\text { structure and defined } \\
\text { roles of personnel to } \\
\text { keep order }\end{array}$ & $\begin{array}{l}\text { conservatively } \\
\text { agricultural } \\
\text { neighborhood }\end{array}$ \\
\hline Red & $\begin{array}{l}\text { where people must } \\
\text { fight for survival }\end{array}$ & $\begin{array}{l}\text { risky and focused on } \\
\text { quick earnings }\end{array}$ & $\begin{array}{l}\text { joining any activity, } \\
\text { giving at hand benefits } \\
\text { personally }\end{array}$ & $\begin{array}{l}\text { following ones the } \\
\text { boss who makes quick } \\
\text { and absolute decisions }\end{array}$ & $\begin{array}{l}\text { deteriorated, while } \\
\text { people did nothing } \\
\text { about it }\end{array}$ \\
\hline
\end{tabular}

Figure 5 Some indicators and measurements in identifying spiritual quality and other sustainable qualities in the remaining three Quadrants.

\section{Case study selection}

According to the conditions of the funding agency, the Thailand Research Fund, Thailand had to be the base of the research and another three countries were allowed for the purpose of conducting additional surveys. The United States and the United Kingdom were selected because they are English speaking countries on different continents. In addition, they have a very long history in the environmental movement and sustainable features for movement and sustainable features for residential design. The Netherlands was selected because it has a very good reputation internationally for quality housing and real estate development. In each of these countries, the most well-known and pioneering form of sustainable residential-development, which included single family homes for the middle-high income group, were selected to avoid financial and knowledge limits of homeowners.

In Thailand, three residential-developments, namely $\mathrm{T} 1, \mathrm{~T} 2$ and $\mathrm{T} 3$, which included single family homes for the middle to high income group, were selected for their difference in nature. Firstly, T1, according to pilot surveys, had the highest degree of sustainability, T2 had a lower degree than T1, and T3 had the lowest. Secondly, T2 and T3 had occupational periods of around five years to allow for upgrades in recent design concepts and technologies, with enough time to allow for a period of occupation. However, T1 had no time 
limit for the selection process, which was necessary in order to include the most sustainable and pioneering project in the country, making it compatible with the overseas ones.

\section{Findings: the communities' establishment and transformation}

To prove that integral sustainability actually needs a spiritual core, the findings from the analysis of relationships among influential forces facilitating a transformation towards integral sustainability in the real estate developments are presented as follows.

\section{The "USA" community}

Among the six case studies, the one which took place in the United States was of the oldest community that was designed in ways believed to be most "sustainable" with reference to current models. The "USA" community was the outcome of life in the 1960s environmental movement with a background in various areas of study, such as architecture and environmental psychology, which together transformed the consciousness of developers to the TURQUOISE meme. In the transformation process, developers became concerned that the world would run out of oil, the world's ecology was unhealthy and people were feeling alienated with a loss of sense of community. Early in the 1970s, the developers assembled like-minded friends on a weekly basis to draft a plan for "building a more socially satisfying and resource-efficient neighborhood." In the beginning, they only wished to publish a book showing their experiences and explaining how this kind of community could be designed in the future. Later, they integrated native wisdom and knowledge from all four Quadrants to complete the design, and used approaches in various memes to overcome problems caused by traditional BLUE and ORANGE perceptions, codes, finance, politics and technologies. Thanks to the demand for a $\square[1 \| \square \square$ $\square \square \square \square \square \square$ and environmental and energy conservation, the properties, as planned, were sold quickly. Moreover, as the developer's overall plan had allowed, most original buyers, having a $\square\|\|\|\| \square \| m$, participated with the developers who had permanently moved into the community, in the design and construction of open spaces and communal buildings, as well as in ongoing community management. Therefore, almost all the sustainable features were

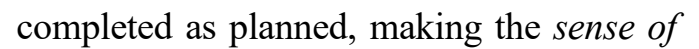
$\square \square \square \square \square$ strong by the end of the project. Although the developers were too exhausted to undertake more projects, they continued to contribute to the sustainable development movement in various approaches and aspects. Their principles and the community sustainability outcome quickly became internationally known as a benchmark demonstration project.

The integral-sustainability qualities of the community at the YELLOW-TURQUOISE level gave knowledge and inspiration to the public. Each year, hundreds of people from overseas visited the community. The price of property has risen continuously for more than 30 years, although the original qualities have degraded somewhat as the community matured. One respondent explained:

... This may be due to the turnover of residents and because the $\square \Pi\|W\|$ $\square \square$ has faded over time ... Perhaps, the biggest challenge to the community is how it can maintain a strong sense of social design as the place ages and matures. The residents will have to work especially hard if they want to sustain this over time. 


\section{The "UK" community}

The community's founding group consisted of three people, who had pursued disciplined spiritual paths for years before they were employed as a hotel management team. They ran the business under divine guidance successfully. However, early in 1960 s, they unexpectedly received dismissal notices and were forced to live with little money and three children in a mobile home, set in a caravan park. Although the land was sandy and dry, they started growing vegetables. Soon, through meditation, they rediscovered that it is possible to communicate with the energy forces controlling the growth of plants and that these forces will respond. Their ecological consciousness developed, they grew many kinds of organic plants and the garden became famous and drew people to join their work. Shortly thereafter, they grew into a small community based on a belief in God and an underlying spirit and intelligence within all beings. There was no formal doctrine or creed but a common understanding that an evolutionary expansion of consciousness was taking place in the world, creating a human culture that is based on love, cooperation, wholeness and respect for all beings, which can be classified as TURQUOISE thinking.

Early in 1970s, this group established a Foundation as a centre for holistic education to demonstrate its work with this emerging consciousness. Later, they were heavily influenced by the 1983 World Wilderness

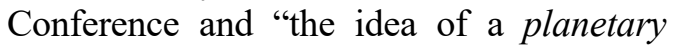
$\square \amalg \Pi$, creating a human ecology in harmony with nature as a model for the planet." Within this group, consciousness transformed to the TURQUOISE meme in many individuals, including one technical engineer consultant to the Foundation. This consultant later became a key person in helping the Foundation form a planning group or developer team for an ecovillage project development as a communal attempt to live more harmoniously with nature by replacing caravans. Responsible for the ongoing planning of the project, the consultant spent many years gathering knowledge and conducting experiments in an effort to create the first planetary village, which featured "a combination of four elements: spirituality, ecological awareness, economic sustainability, and a nurturing cultural and social atmosphere." Meanwhile, the Foundation created many activities, including green businesses, healthcare, environmental conservation and restoration programs. By the end of 1980s, with significant external cooperation and sponsorship, caravans began to be replaced by new eco-houses built to high standards in both practical and fantastic designs. A few years later, the engineer-consultant published his first book, based on research and experience gained in developing the ecovillage project. It became the United Kingdom's first technical guide to ecological housing and helped the ecovillage project become a major resource for environmental education locally, nationally and internationally. In 1995, their group became a founding member of the Global Ecovillage Network; the Ecovillage Training program of which later received institutional endorsement from the United Nations.

The community experienced both positive and problematic changes since its beginning, mainly due to the high number of guests interested in the community's integral activities that seek to bring all four Quadrants to the TURQUOISE level. Community issues varied from simple ones that everyone could face to complex ones that only those living in

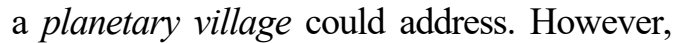


these were all superficial. As a noted community member wrote:

... even though personalities were changing and settings and phases came and went, members and guests continued to learn to live together with love, awakening their connection with their inner truth, and thus making a self-transformation. On whatever level that transformation had occurred, most people left to share it in their home environment ... This is the true and simple history of the ... Foundation, and it continues today.

\section{The "NL" community}

In the early 1970s, the Club of Rome's report on $\square \square \square \| \square \square \square \square \square$ and the oil crisis were key factors that helped transform the consciousness of a significant number of Dutch people to the TURQUOISE meme; and subsequently led to major changes in Dutch policies and measures towards sustainability. In the mid-1980s, as the interdisciplinary planning approach was increasingly adopted in the field of ecological urban development, the idea of environmental awareness and energy-saving building projects gained momentum in government. A team, consisting of an architecture firm, an engineering firm and a university, proposed to the government the building of a Dutch demonstration project applying various options for sustainable design and real estate construction to promote a rapid acceptance of sustainable building by mainstream residential-developers. By the end of 1980s, two public agencies had joined forces and commissioned preliminary research on project feasibility, including an inquiry of key participants to develop a broad consensus about environmental building and conservation principles and to identify a range of sustainable real estate solutions. Then a public agency specializing in energy and environmental conservation research and one of the biggest Dutch international real estate development companies joined forces as the developer. Many architecture firms were selected. Each supplied specific sustainable design features for the houses located in groups. A foreign architect-planner was asked to design the community layout.

In spite of significant frustration-including the administrative insistence on responsibilities and inexperience in executing a sophisticated model project that made the planner leave before construction started - the whole project, consisting of more than a hundred houses, was completed within a year. A close working relationships among parties, a number of workshops and informative sessions, characteristics of the Dutch culture, and intensive government support were key factors in enabling the completion of this project. A few years later, experts evaluated it and concluded that it was a remarkable achievement in several areas of sustainability. However, since the architects and developers were not focused on spiritual and cultural importance, i.e., the $\square \square \square \square \square$ dimensions of sustainability; and because individualism - in the ORANGE meme-dominates Dutch culture, the achievement essentially covered only technological and environmental dimensions, i.e., the physical or $\square\|\| \| \square$ dimensions of sustainability. So, the ORANGE self and behavior of homeowners that characterized the early period were detected in this research. However, as residents continued to live in this community, they transformed to the GREEN-YELLOW level due to environmental influence, including a community pond of high ecological quality, self-sufficient housing and friendly neighbors. In contrast, environmental and social issues brought about by new residents were cited by the survey respondents as the 
main obstacle to a community transformation towards sustainability.

\section{The "T1" community}

In October 1973, while the first world oil crisis was the main issue in major industrial countries, the first and biggest socialmovement, led by university students, protested against Thailand's RED-BLUE dictatorial government and a considerable number of students died from the government's use of force during the uprising. This event transformed the "T1" project developer's social awareness while the acts and teachings of one of his lecturers in the school of architecture transformed his environmental awareness. Upon graduation, he and his friends set up a small design firm with a passion for creating innovative socially responsible architecture. They combined commitments to excellence and to Thai society and were at the cutting edge of innovative design. In the early 1980s, when the Thai bubbleeconomy formed and most firms followed a Western style, they started to produce housing designs that integrated modern living and technology with local characteristics, including culture, climate and images drawn from local wisdom. They received significant awards and a return on their investment and were, therefore, able to carry out many social and environmental projects, in urban and rural areas, mostly without fees. They set up a development firm with the expectation of significant funding to build the first Children's Discovery Museum in Thailand. They started to study the $\square \square \square \square \square$ deeply and established a foundation as the centre for holistic education to support and work with the new form of consciousness, the emerging TURQUOISE meme, similar to the "UK" community. The "T1" community was their last project before they shifted from business to social work, after the bubble-economy crisis of 1997. The "T1" community received an award for innovation and became known as a highly ecological and socially-bonding community. The design and project development businesses were handed over to successors. However, later projects never achieved the original sustainability goals because the successors did not any longer pay much attention to creating innovation with a social and ecological awareness.

In the beginning, due to well-integrated design and a commitment to creating innovation and social responsibility, the "T1" project attracted many socially and environmentally conscious people from various professions as residents. These people contributed to the GREENYELLOW level of the community's sustainability qualities in the four Quadrants. These qualities intensified as residents continued to live in this community thanks to their social and environmental culture and their awareness, occupations, the community management system and the physical environment. Here, the main challenges found were how residents could continue the sustainability features when they modified or expanded their private properties and how to promote more sustainable lifestyles as desired by homeowner association leaders.

\section{The "T2" community}

The developer of this community was a leading public company in the Thai housing sector. During the bubble-economy, with ORANGE qualities, the company drew a large amount of foreign funding to retain its competitive position leading to huge debts when the $\square \Pi \| \square$ burst. The board of directors, including the company founder who had an engineering and family-business 
background, decided to use strong marketing and architectural research to overcome the financial crisis. This provided opportunities for an in-house architect with some GREEN qualities, developed partly from Buddhist practice, to insert sustainable features into his innovative designs. Some of these features became standard for Thai housing developments. With effective marketing strategies and ideal locations, the projects were very successful. Consequently, the company fully recovered in just a couple years and has maintained its position in the real estate market but unfortunately has discontinued its sustainable-design developments.

Because the developer only emphasized new customer sales, the quality of the after-sales service was poor. Many defects resulted from poor construction, public facilities were not provided in a timely manner and there were many complaints. Moreover, the money collected from residents for public services was not used transparently by the developer. Residents were forced to expel the developer and set up a homeowners' association so they could supervise the property management. This led to an increased $\square\|\| \| \square \square \square \square \square \square \square$, especially neighborliness and the appearance of GREEN awareness in what had been an ORANGE dominated community. As residents continued to live in this community, they gained GREEN and YELLOW qualities through an increased awareness of social participation, knowledge about the side effects of consumerism and integral thinking. Nevertheless, since ORANGE is still powerful, most residents worry about security, the quality of the management and the ability of the services to sustain their "good life", rather than integral sustainable-living.

\section{The "T3" community}

The developer of this community is another leading public company but approaches business ideas and operations differently from the "T2" developer. The founder began his career in a business dominated by ORANGE and RED thought. Once he saw an opportunity and his personal relationships with politicians and authorities had become strong, he procured a very large amount of land and successfully developed projects with a quality higher than the market standard. During the bubble-economy, he

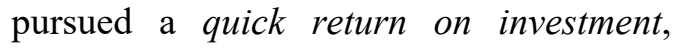
including the sale of vacant lands to buyers contracted to complete the construction of houses within five years. He urged his staff, including architects, to look after customers, even by omitting basic design principles. Dazzled by the rapid industrial growth, RED dominated individuals scrambled for land with or without a house. Unfortunately, the economic downturn created a serious trade deficit, foreign debts were overwhelming and most buyers were unable to make payments because many had bought properties speculatively. Rather than paying attention to product research and development, the developers had used traditional marketing-techniques to generate income. Those methods were only adequate for a limited financial recovery and many plots were not sold. Moreover, the contract to make land-buyers build houses within five years could not be enforced and the publicservice fee could not be collected as planned. So, some gardens, community building and most of the sustainable features planned by the in-house architect with a few GREEN qualities were left out. This caused high dissatisfaction among the homeowners. Later, many homeowners stopped paying the management fees, resulting in reduced level of service and maintenance by the developer. 
Due to ORANGE domination and the appearance of RED for almost six years after most of the homeowners had moved in, no public area was designated for communal activities. Also, many public and private areas were in very poor condition by the time a homeowners' association was formed to demand tangible improvements from the developer. During this challenging period, GREEN and YELLOW qualities, such as participative action and integral ideas, emerged. However, after solutions were agreed upon and partly implemented, these qualities faded; making the sustainable futures of this community unpromising.

\section{Reflection on the research findings}

From the findings, explanations concerning three key questions are presented as follows.

\section{Has integral transformation occurred in the community development process?}

Analysis of the development process of the "USA", "UK", "NL", and "T1" sustainable communities has shown that all developers shifted spiritually far away from egoism, in response to a perceived environmental crisis. With a new paradigm and a basis for success-including aspiration, exertion, thoughtfulness and reasoning as explained by Dhammapitaka (2000: 186) - they sought new knowledge through research and experimentation and created long-term plans. Simultaneously, they gathered together people who shared ideas of integral thinking to participate in sustainable designs, rather than focusing on high profit. As other cultural and social factors in the wider society supported their ideas and actions, a model of sustainable communities with better social and environmental qualities emerged in each country. Various "green" codes and standards were created as a result of these phenomena.

To conclude, this analysis proves that integral transformation - a development to the higher level in all Quadrants - occurred in the community development process, thus confirming the concept of interdependent relationship in integral theories.

\section{What were the factors that enabled this shift?}

Because integral thinkers, such as Dhammapitaka (2001: 247) and Wilber (2000: 54), assert that spiritual lifequalities carry the coded instructions of thinking systems and actions, it can be said that spiritual transformation enabled the transformation process described in the past question. Nonetheless, in order to enhance understanding, this study further investigated personal transformation. It found that various conditions in people's lives were involved in the transitional process. Certainly, social and environmental crises were major influences. Others included a search for knowledge and self-practice, the interaction with good people, local culture, books, media, nature and social movements.

\section{How do sustainability and spirituality relate in community development and transformation?}

This study asserts that the degree of sustainability in real estate design, for pioneering purposes, depends foremost on the spirituality of the developers and designers. Having the highest degree of consciousness, the "UK" developer created a community with the highest degree of sustainability. Having a progressively lower 
level of consciousness, the "USA", "T1" and "NL" developers created communities with lower degrees of sustainability respectively. It should be noted that even though having only a little GREEN consciousness, the "T2" and "T3" designers inserted a few sustainable features into the communities they created.

Furthermore, research indicated that the degree of sustainability in any community also depends on the spiritual quality of its residents. In detail, the "UK" TURQUOISE community was created and has been maintained by people who possess TURQUOISE consciousness. The YELLOW-TURQUOISE qualities of the "USA" community partly degraded as the social and environmental awareness of its residents faded. The communal activities in the "NL" community have been poor, as the ORANGE spirituality of its residents represents intense individuality. Also, RED qualities appeared in "T3" mainly as the result of the ego and selfishness possessed by its residents.

\section{Conclusions and recommendations}

Analysis of the findings of this research shows that a transformation toward integral sustainability has been occurring in the real estate industry.

However, this shift was delayed when the power of undeveloped spirituality was overwhelming. The power of RED and ORANGE memes has been particularly powerful in blocking social and natural shifts. One clear example revealed by this study is the financial and environmental unsustainability generated by RED and ORANGE spirituality during "T3" community formation and conversion.

Therefore, this study offers Figure 6 as a new model of development to facilitate transformation towards an integral approach to sustainability. This model shows how initial activities supporting spiritual development must be immediately and widely implemented as this dimension is highly crucial to global revitalization. Once spirituality is raised, at least to the integral or YELLOW level, ignorance, ego and selfishness sufficiently fade at the transitional stage of self-transformation. As a result, aspiration, exertion, thoughtfulness and reasoning become so strong that people with these qualities are able to seek new knowledge through research, experimentation, the creation of long-term plans and gathering people with similar integral thinking to benefit from other supportive conditions in the wider society. Eventually, sustainable real estate, and even integral sustainability, can be realized. 


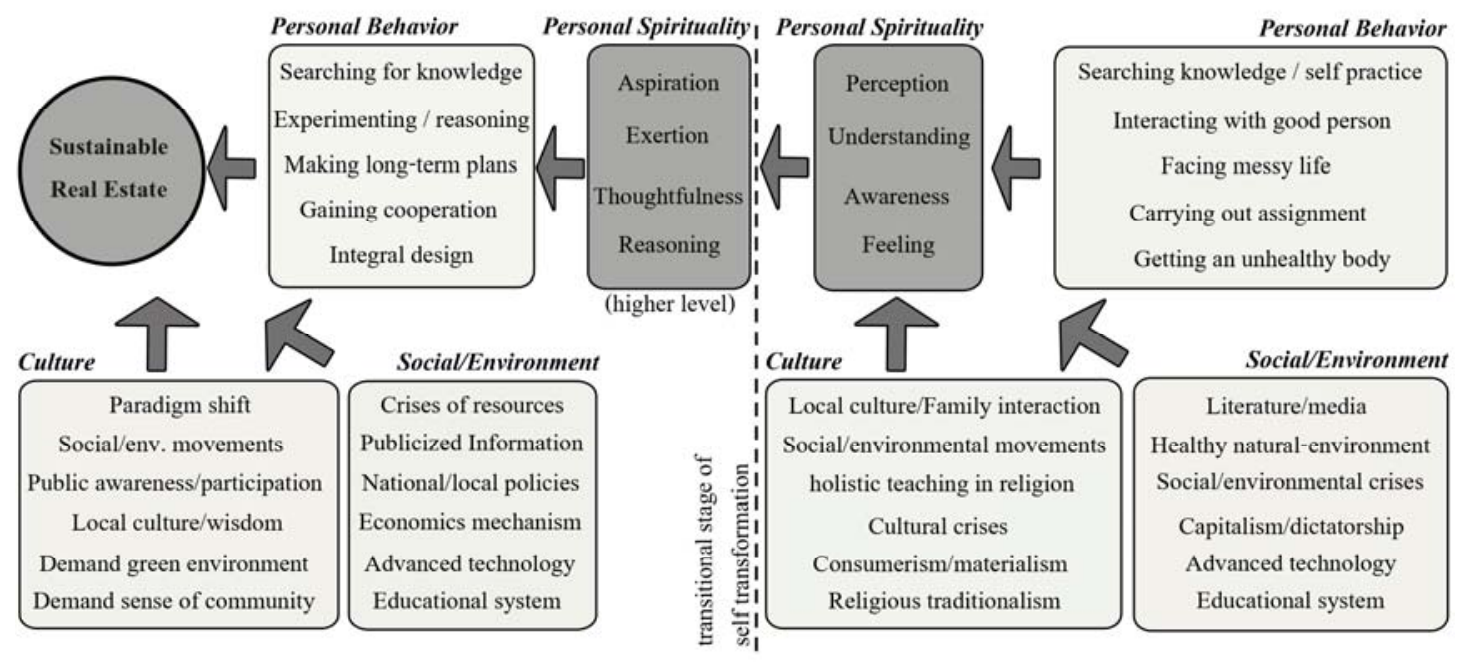

Figure 6 Integral Model of Sustainable Development

\section{Epilogue}

This internationally comparative research investigates how sustainable real estate development transformation is facilitated and evaluates the degree of sustainability created in six urban communities. The findings reveal that integral transformation occurred - embracing spiritual, behavioral, cultural, social and environmental transformation to a higher degree of sustainability. The findings also reveal that spiritual transformation is the primary factor facilitating this occurrence.

Although this research focuses on the real estate industry, the importance of the findings is their applicability to mainstream developments in the wider society. The finding confirm the contention of this study that healthy sustainability depends on healthy evolution in all human dimensions - all four Quadrants formed by two axes (internal-external; individualcollective) and that individual spirituality is the limiting factor in the shift to integral thinking and development.

Therefore, it is expected that the findings will create interest in enhancing the quality of life - especially within the inner dimensions of mind and culture-by integral thinking and practices as Wilber (2000: 138-139) suggests. Shifting to this new thinking will be very difficult but, according to Kuhn (1970: 10-22), many great thinkers have gone through paradigm shifts throughout history. This shift can start by challenging the belief that motivating society with money, economics or narrowly focused tools is universally practical. This can lead to learning that money is just one tool that must be used together with other tools such as technology, culture and love. This knowledge can combine with effort and persistence to protect the self from ego and selfishness. Accordingly, the individual can grow to realize the self as only a tiny part of the universe. Then, the individual can stop separating culture, such as native knowledge 
and belief, from technological advancement and cease to believe that Buddhism, sustainable development and other approaches outside mainstream economic ones will slow down economic activities.

In making this shift, one's understanding of interconnectedness will significantly increase. Integration and integral thinking will become the norm. Houses and communities will be created in a more sustainable manner, with love for the holistic well being of nature, humankind and all living things.

\section{Acknowledgements}

This article is based on "The Transformation Process toward Sustainable Real Estate Development: from an Egocentric to Integral Paradigm," Ph.D. dissertation (in Thai), sponsored by the Royal Golden Jubilee Ph.D. Grant, awarded by the Thailand Research Fund (TRF). The main author would like to thank the TRF for funding the research for this paper and to extend his gratitude to his dissertation committee, as well as his abroad co-advisor for their academic and moral support.

\section{References}

Beck, Don Edward. 2001. Sustainable Cultures, Sustainable Planet: a Values System Perspective on Constructive Dialogue and Cooperative Action. Paper

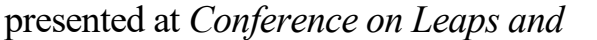

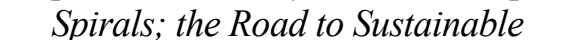

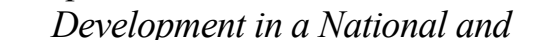

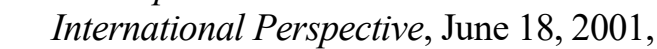
milleeuwarden, The Netherlands.

Beck, Don Edward. 2004. Spiral Dynamics

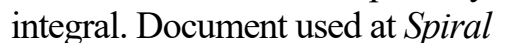

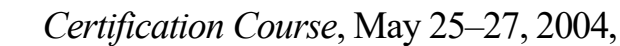
indinallas.

Beck, Don Edward, and Cowan, Christopher C. 2001. $\square\|\|\|\| \| \square \square \square .9^{\text {th }}$ edition. Malden, Massachusetts: Blackwell Publishers.

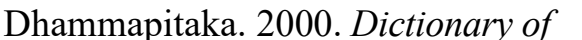

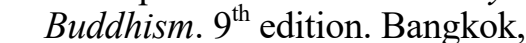
WThailand: Mahachulalongkomrajavidyalaya University Press.

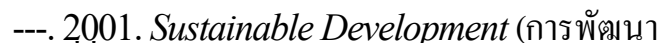
ที่ยั่งยืน). $8^{\text {th }}$ edition. Bangkok, Thailand:

पा山mol Keemthong Foundation Press. (in Thai)

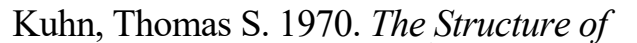

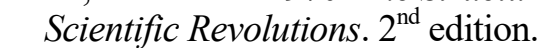

때 Chicago, The University of Chicago Press.

Motloch, John L. and Casagrande, Eloy F. 2005. Sustaining the US- Brazil Sustainability Consortium through Project Partnering. Paper presented at $\square$

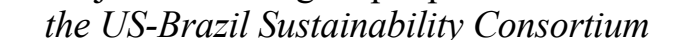

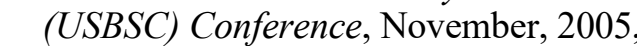

WWashington D.C.

Puntasen, Apichai. 2000a. $\square \square \square \square|m| m$

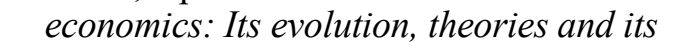

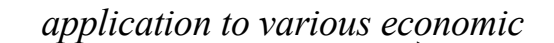

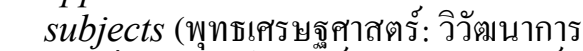
ทฤษฎี และการประยุกต์กับเศรษฐศาสตร์สาขา ต่าง ๆ). $2^{\text {nd }}$ edition. Bangkok, Thailand:

ए।Amarin Printing and Publishing. (in Thai)

---. 2000b. Economic Ethics, Environment and Buddhist Economics, Paper

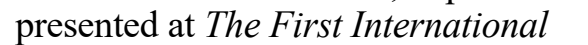

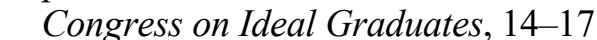

November, 2000, Bangkok, Thailand.

Santitham, Kunnatham. 2006. Planning and Management toward a Green and 
Clean University: Thammasat

University, Rangsit Campus (แนวทางการ

ปรับปรุงผังบริเวณและการจัดการสู่

มหาวิทยาลัยเขียวสะอาด: มหาวิทยาลัย

ธรรมศาสตร์ ศูนย์รังสิต). $\square \square \| \square|W| \square$

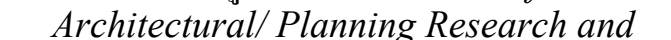

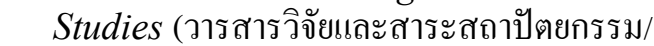
การผังเมือง), Vol.4.2: 157-184. (in Thai)

Schumacher, E.F. 1973.

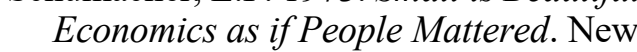

ㄸIIYork: Harper \& Row, Publishers.

Segschneider, Karl. 2002.

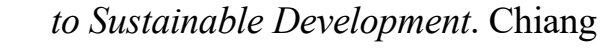

mIMai, Thailand: Heinrich-Boll

Foundation.

TangJai, Prasarn. 1995.

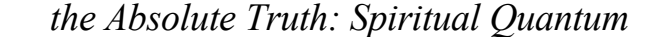

(จักรวาลกับสัจธรรม แควนตัมจิตวิญญาณ).

Bangkok, Thailand: Green Peace.

(in Thai)

Toga, Arthur W. 2002. Brain. $\square \square\|\| \square \square m$

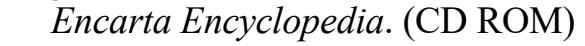

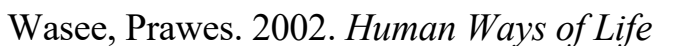

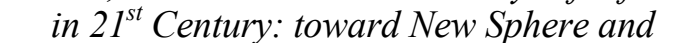

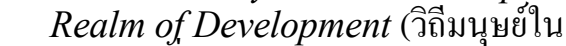

ศตวรรษที่ 21 : สู่ภพภูมิใหม่แห่งการพัฒนา) $\square$

WCED (World Commission on

Environment and Development). 1989.

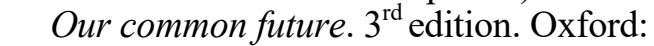

minford University Press.

Wilber, Ken. 2000.

Boston: Shambhala.

Buddhadasa. 1990.

पाणापाणए. June 19, 2004

$<$ http://www.suanmokkh.

org/archive/ecology1.htm>.

Beck, Don Edward.

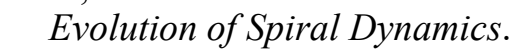

December 19, 2006<http://spiral

dynamics.net/evolution.Shtml .
Wilber, Ken. unidentified year-a. $\square \square \square\|ा\| \Pi \square$

पाणाणा।णाD December 19, 2006

$<\mathrm{http}: / /$ www.integralnaked.

org/faq-pdf.aspx?id=2>.

Wilber, Ken. unidentified year-b.

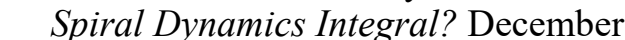
$19,2006<\mathrm{http}: / /$ www.integralnaked. org/faq-pdf.aspx? id=6>. 